\title{
Examining the relationship between diet-induced acidosis and cancer
}

\author{
lan Forrest Robey
}

\begin{abstract}
Increased cancer risk is associated with select dietary factors. Dietary lifestyles can alter systemic acid-base balance over time. Acidogenic diets, which are typically high in animal protein and salt and low in fruits and vegetables, can lead to a sub-clinical or low-grade state of metabolic acidosis. The relationship between diet and cancer risk prompts questions about the role of acidosis in the initiation and progression of cancer. Cancer is triggered by genetic and epigenetic perturbations in the normal cell, but it has become clear that microenvironmental and systemic factors exert modifying effects on cancer cell development. While there are no studies showing a direct link between diet-induced acidosis and cancer, acid-base disequilibrium has been shown to modulate molecular activity including adrenal glucocorticoid, insulin growth factor (IGF-1), and adipocyte cytokine signaling, dysregulated cellular metabolism, and osteoclast activation, which may serve as intermediary or downstream effectors of carcinogenesis or tumor promotion. In short, diet-induced acidosis may influence molecular activities at the cellular level that promote carcinogenesis or tumor progression. This review defines the relationship between dietary lifestyle and acid-base balance and discusses the potential consequences of diet-induced acidosis and cancer occurrence or progression.
\end{abstract}

Keywords: Acid-base balance, Diet, Acidosis, Cancer

\section{Diet, cancer, and 'acidity'}

The relationship between diet and cancer is well known [1-3]. Dietary intake exists as the largest external or environmental epigenetic factor capable of driving the development or maintenance of cancer. The American Institute for Cancer Research (AICR) comprehensive global report has compiled numerous studies demonstrating associations between dietary habits and cancer risk [4]. The findings recommend increased or regular consumption of vegetables, fruits, whole grains, and legumes, while discouraging excess consumption of sugary and energy-dense foods and drinks, red and processed meats, and salty processed foods (www.aicr.org).

Acidity is a well known factor associated with cancer. Lower $\mathrm{pH}$ levels in the extracellular space promote the invasive and metastatic potential of cancer cells [5-14]. Extracellular acidity is mostly generated by tumor cells due to upregulated proton $\left[\mathrm{H}^{+}\right]$and lactic acid production [15]. This phenomenon is distinct from 'acidity'

Correspondence: robeyi@email.arizona.edu

Arizona Respiratory Center, University of Arizona, 1501 N. Campbell Ave., Suite 2349, PO Box 245030, Tucson, Arizona 85724, USA caused by a net-acid diet. A net-acid diet or acidogenic diet is determined by the balance between acid and base-forming dietary constituents. Most fruits and vegetables are net-base producing foods since the metabolized products are organic anion precursors such as citrate, succinate, and conjugate bases of carboxylic acids [16-18]. The final metabolite of these precursors is bicarbonate anion. Sulfur containing amino acids, methionine and cysteine, typically found in meats, eggs and dairy products, are oxidized into sulfuric acid which is ultimately net-acid producing [16]. Cationic amino acids such as lysine and arginine can be acid producing if their anionic counterpart is chloride, sulfate, or phosphate. However, if the anionic component is a metabolizable organic acid (glutamate or aspartate), there is almost no impact on systemic acidity $[17,18]$. Other dietary factors are known to influence acid-base status as well. Sodium chloride is reported to be an independent and causal factor for inducing metabolic acidosis in a dose-dependent manner $[19,20]$. Conversely, potassium salts, and to a lesser degree magnesium, serve as a countervailing effect on net acid excretion and help to promote alkaline balance $[21,22]$. 
Acidogenic dietary intake such as high protein consumption can have an immediate effect on increasing net acid production while low protein lacto-vegetarian consumption can result in significantly reduced net acid excretion [23,24]. Short-term dietetic acid loading may cause temporary acid-base disequilibrium, but is quickly compensated and has no measureable clinical effect. A persistent acidogenic diet, however, raises the likelihood of an increased $\left[\mathrm{H}^{+}\right]$surplus and chronically lower levels of serum bicarbonate if compensatory processes become less efficient and are unresolved by dietary adjustments. Potential long-term effects of acidogenic diets are further compounded by the reduction of renal function typically from ageing [16,25-28].

Blood $\mathrm{pH}$ from prolonged or chronic acidogenic diets is reported to be near the lower physiological range (7.36-7.38) rather than the higher end (7.42-7.44). Specifically, persistent acidogenic diets have the potential to cause small decreases in blood $\mathrm{pH}$ and plasma bicarbonate, but not beyond the normal physiological range. This condition is described as 'diet-induced, 'low-grade', or 'chronic metabolic acidosis' [28-30] or sometimes 'latent acidosis' [31]. Diet-induced acidosis is distinct from clinical metabolic acidosis in that clinical metabolic acidosis occurs when factors other than just acidogenic diet contribute a system's inability to compensate for blood $\left[\mathrm{H}^{+}\right]$ perturbations, typically resulting in blood $\mathrm{pH}$ below 7.35 [32]. The patho-physiological effects of clinical metabolic acidosis are well known [33], while the true pathophysiological impact of long-term, diet-induced acidosis is not well understood. For example, it is unknown if $\left[\mathrm{H}^{+}\right]$accumulation from chronic diet-induced acidosis can be stored at the cellular level if it does not play a role in lowering blood $\mathrm{pH}$ or is compensated by competent renal or respiratory function. Studies of the impact of clinical metabolic acidosis on biological systems may still be informative towards understanding the effects of dietinduced acidosis because they examine how acid-base disequilibrium causes physiological stress and influences molecular pathways active in disease processes [34].

It is generally understood that the cancer condition evolves from genetic and epigenetic changes in the normal cell. Both microenvironmental and systemic factors exert selective pressures that aid in the initiation or aggravation of tumors. Acid-base disequilibrium is considered a type of systemic stress. With the understanding that long-term acidogenic diets potentially exert chronic physiological stress, the question proposed here is: Can diet-induced acidosis increase cancer risk or promote existing tumors?

\section{Cortisol}

\section{Cortisol and acid-base balance}

Acid-base balance in the body influences adrenal hormone production of cortisol. When bicarbonate $\left[\mathrm{HCO}_{3}^{-}\right]$ levels are low the kidneys upregulate glutaminase activity and trigger cortisol production [35-37]. Studies in animals and humans have reported that system cortisol levels are enhanced by acid-base disruption through transiently induced metabolic acidosis [37]. Acidosis appears to mediate cortisol activity through the pituitary-adrenal cortexrenal glutaminase I axis [37]. Dietary induction of acidosis increases serum cortisol concentrations [38]. In healthy adult humans serum and salivary cortisol is increased significantly within hours after a high protein meal, and cortisol levels were dependent on the protein content of the meals $[39,40]$.

The converse to these findings is shown in a study designed to neutralize the acidogenic effect of the 'Western' diet, characterized by a high consumption of meat, salt, sugar and fat, and proportionately lower intake of fruit, vegetables, and whole grains. The relationship to cortisol levels and acid-base status were examined in six healthy men and three women measuring serum and urine cortisol concentrations along with cortisol metabolite levels (tetrahydrocortisone and tetrahydrocortisol) in the urine of individuals with sodium and potassium chloride replaced with equimolar amounts of sodium and potassium bicarbonate in an otherwise similar diet under "metabolic ward conditions". Within 24 hours, urinary and plasma cortisol and corresponding metabolites were significantly lower, signaling lower cortisol production and activity. Urinary $\mathrm{pH}$ and serum $\left[\mathrm{NaHCO}_{3}^{-}\right]$levels increased while serum $\mathrm{pH}$ remained stable [41].

Not all studies report a positive correlation between high protein, potentially acidogenic diets, and cortisol levels. These studies did not assess acid-base balance in their experimental populations so it is difficult to confirm if these studies are directly comparable to findings linking acidogenic dietary intake and increased cortisol production. It is likely that factors such as gender and body mass index are relevant inconsistencies between various reports [42-44].

Many of these studies suggest there may be a role for diet-induced acidosis in modulating systemic cortisol levels, and that neutralization of acid loading through alkalinization may reduce cortisol levels. Moreover, most of the studies evaluating the role of acidogenic intake on cortisol demonstrate that the interventions had an acute and dose-dependent effect on cortisol levels, suggesting a direct or closely linked dynamic between acid-base status and system cortisol levels. Finally, the studies show that diet-induced acidosis is mild and subsequent induction of cortisol activity, although higher in serum concentration, is sub-clinical and within the normal serum range [41]. If there were pathophysiological consequences it could only be derived from chronic or persistent conditions maintained on an acidogenic diet. 


\section{Cortisol bioactivity in cancer}

There is no clear mechanism linking cortisol bioactivity directly with carcinogenesis, but studies have reported that cortisol signaling may exert biological influence on existing tumors. Androgen-independent prostate tumors expressing high levels of androgen receptor can be stimulated by cortisol and its metabolite cortisone, resulting in growth promotion and proliferation. The mechanism for this interaction is made possible due to a mutation in the androgen receptor that favors 'promiscuous' binding of additional signaling molecules like glucocorticoids [45]. In some breast cancer studies glucocorticoids suppress growth by blocking cell cycle progression [46]. Tumor inhibition appears to be androgen dependent at least in some cell lines [47,48]. In colon cancer, cortisol signaling inhibits $11 \beta$-hydroxysteroid dehydrogenase 2 (11ßHSD2) enzymatic activity which prevents activation of the COX-2 tumor promoter, an early activation marker for colon carcinogenesis. The diversity of tumor responses to glucocorticoid signaling suggests that the relationship between hormonal activity and tumor regulation is receiver-dependent. The following sub-sections discuss the possible indirect role of cortisol signaling in cancer risk and carcinogenesis.

\section{Cortisol and tryptophan metabolism}

Cortisol activates the tryptophan metabolism pathway which is carried out by rate-limiting enzymes of tryptophan catabolism, 2,3-dioxygenase (TDO) and indoleamine 2,3-dioxygenase (IDO). Cortisol directly stimulates TDO activation and may augment IDO activity indirectly through inflammatory cytokine signaling such as interferon gamma [49,50]. Excessive or chronic cortisol production acquired from a 'Western' dietary lifestyle could play a role in augmenting the tryptophan metabolism pathway and drive downstream molecular events that promote carcinogenesis.

The product of TDO and IDO activity, kynurenine, has several roles in promoting tumorigenesis. Kynurenine inhibits the activation of effector T-cells when tryptophan levels are low. Incapacitating effector T-cell function is suggested as an important component in increasing vulnerability to tumor development [51-53]. Tryptophan metabolism also promotes immune tolerance of professional antigen presenting cells (APCs) which are critical in activating other immune cells $[51,53,54]$. Finally, kynurenine binds to aryl hydrocarbon receptor (AHR), which mediates TDO and IDO signaling in regulatory T-cells. The activated AHR suppresses the stimulation of regulatory T-cells involved in inhibiting early tumor development [51,55-57]. The connection between diet-induced, lowgrade hypercorticoidism and the effect on tryptophan metabolism to subsequently promote tumor development has not been adequately explored. Furthermore, it is unknown what other factors may enhance, regulate, or attenuate these signaling events, but a persistent reduction of effective immune surveillance capability promoted indirectly by diet-induced acidosis could cultivate microenvironmental conditions favorable for oncogenic cells to develop metastatic potential.

\section{Cortisol and insulin resistance}

Upregulated cortisol bioactivity driven by diet-induced acidosis may be a factor in metabolic syndrome by promoting insulin resistance. Chronic hyperglucocorticoidism upregulates visceral obesity while reducing insulin sensitivity mainly in visceral adipocytes which appear to be more responsive to cortisol than subcutaneous adipocytes due to higher expression levels of glucocorticoid receptors $[58,59]$. Visceral adipocytes also exhibit greater 11ßHSD1 activity, which converts cortisone to bioactive cortisol [60]. Glucocorticoids stimulate visceral adipocytes to increase the activity of lipoprotein lipases, while simultaneously suppressing insulin mediated glucose uptake [61-66]. This phenomenon suggests that cortisol activated adipocytes are less efficient in storing fatty acids which tend to increase the level of free fatty acids in circulation and contributes to diminished insulin sensitivity [67].

Glucocorticoid signaling promotes insulin resistance through other signaling pathways as well. Insulin stimulated glucose transporter-4. (GLUT-4) translocation to the cell surface of adipose tissue is suppressed by glucocorticoids. Cortisol directly inhibits insulin secretion from pancreatic beta cells. Finally, cortisol can reduce insulin mediated vasodilation of endothelial cells, and suppresses peripheral insulin driven glucose uptake [68-70].

Acidosis associated insulin resistance through cortisol activity may result in compensatory pancreatic insulin secretion and higher levels of circulating insulin in the serum, a condition known as hyperinsulinemia. Epidemiology studies have shown a positive correlation between circulating insulin levels and increased risk and pathogenesis of colorectal and pancreatic cancers [71-76], cancers of the endometrium [77], kidney cancer [78] and breast cancer $[79,80]$. Longitudinal studies report a higher risk for breast cancer in women with hyperinsulinemia [81-83]. Human studies are confirmed by experimental data showing that injected insulin promotes tumorigenesis in animal models for colon [84] and breast $[85,86]$ cancer. Insulin deficiency or insulin blocking reduces tumor incidence or progression and is reversible with re-introduction of insulin [87]. Several of the study findings conclude that hyperinsulinemia is an independent risk factor from obesity and diabetes [88].

Insulin is a pleiotropic hormone with both mitogenic and metabolic properties. It binds with the highest affinity to its own receptor and with lower affinity to the 
insulin growth factor-1 (IGF-1) receptor. The insulin receptor exists in two isoforms, IR-A and IR-B. IR-A is expressed at lower levels than IR-B, but has greater mitogenic activity when stimulated by insulin. Additionally, both insulin receptor isoforms can form heterodimeric complexes with the IGF-1 receptor. The IR-A/IGF hybrid receptor is expressed in all human tissues and binds to insulin with high affinity [89]. Activation of these receptors by insulin stimulates cellular transformation and promotes malignancy. Insulin promotes cellular proliferation, migration, and cellular survival mainly through the MAPK pathway and sometimes through PI3K pathway [88]. It is proposed that chronically exposed cells to even moderately elevated insulin levels may favor cell proliferation and subsequently increase the risk for malignant transformation [89]. Thus, persistent diet-induced acidosis favorable for maintaining chronically high levels of cortisol could be supportive of insulin sensitized tumor development.

\section{Insulin growth factor}

Studies examining the relationship between diet-induced acidosis and insulin growth factor (IGF-1) levels have varied outcomes. Acute induction of systemic acidosis appears to reduce serum IGF-1 levels. Short-term (5-7 days) induction of metabolic acidosis in healthy male subjects using ammonium chloride $\left(\mathrm{NH}_{4} \mathrm{Cl}\right)$ causes a significant reduction in serum IGF-1 levels [90], confirming the results of an animal study carried out under similar parameters [91]. An adult fasting between 5-10 days induces a mild metabolic acidosis and appears to have the effect of reducing plasma IGF-1 concentrations as well [92-94]. Plasma IGF-1 levels are doubled by treatment with bicarbonate in individuals with renal tubular acidosis [95]. In healthy subjects though, neutralization of diet-induced acidosis with bicarbonate treatment for a 7 day period does not have a significant impact on IGF-1 levels [41].

High protein consumption over long-term periods (months to years), which promotes greater net acid production and subsequent latent or low-grade metabolic acidosis, appears to have the opposite outcome from short term studies on IGF-1 levels. Studies conducted for 12 weeks or longer revealed a strong correlation between increased dietary protein and higher serum IGF-1 levels, suggesting at least long-term dietary habits, not short-term perturbations, significantly impact IGF-1 serum concentrations [96-99]. Another epidemiological study in healthy middle-aged and elderly male participants concluded that while protein consumption was positively correlated to serum IGF-1 levels, the finding was only consistent in individuals with a body mass index (BMI) of $<25 \mathrm{~kg} / \mathrm{m}^{2}$. There was no significant relationship between protein consumption and IGF-1 levels in obese individuals $\left(\mathrm{BMI}>25 \mathrm{~kg} / \mathrm{m}^{2}\right)$. The study also reported that even while protein consumption increased IGF-1 serum levels, there was an age dependent decline in IGF-1 levels overall [100]. The findings suggest a potential for chronic acidogenic or 'Western' diets to elevate IGF-1, but other factors complicate this dynamic and require additional study. While it is reasonable to predict that the individuals in these long-term studies have developed low-grade acidosis from their diet, it does not mean that acidosis is a driver of IGF-1 upregulation. Furthermore, if diet-induced acidity upregulates IGF-1, as suggested from the long-term dietary studies, it is not yet determined if this occurs directly or indirectly through cortisol signaling $[2,88,89]$.

IGF-1 binding to the insulin receptor has been shown to inhibit apoptosis and increase target cell proliferation, thus linking its signaling activity to the risk of different forms of cancer [101-103]. Several case control studies have demonstrated a possible link between IGF-1 bioactivity and different cancers including prostate [104,105], colorectal [106-108], and breast [109]. The serum IGF-1concentrations in the case population of the studies were relatively consistent with the ranges measured in the previously discussed studies evaluating the effects of 'Western' diet consumption on IGF-1 levels [97,100]. IGF-1 median levels of about 200ng/ml in individuals younger than 70 years of age were typically associated with high protein diets ( 90-105 g/day).

\section{Adipokines}

Leptin

Leptin is an adipocyte derived hormone cytokine that plays a role in regulating body weight and energy balance in the hypothalamus [110]. Metabolic acidosis modulates lipid metabolism in adipocytes [111-114]. Acidosis reduces leptin concentrations in cultured adipocytes [112]. In uraemic Wistar rats, sodium bicarbonate supplementation appeared to increase (but not significantly) leptin levels [113]. A study in chronic kidney disease (CKD) patients with metabolic acidosis revealed that serum leptin was significantly increased by treating patients with a daily low to moderate dose $(0.05-0.2 \mathrm{~g} / \mathrm{kg})$ of sodium bicarbonate. The report concluded that either reversal of acidosis increases serum leptin or metabolic acidosis masks serum leptin levels [114].

Studies comparing serum leptin between healthy individuals consuming acidogenic type diets and those consuming more alkaline types of diets present mixed and variable findings. A study in men and women compared serum leptin levels between a group of 279 people consuming a diet rich in fish and a group of 329 people consuming a strictly vegetarian diet. Fish consumption is a high net acid producing diet [16]. Both groups had 
similar BMI values. The study was consistent with findings from in vitro, and animal investigations in that it reported the protein-rich diet was associated with significantly lower levels of serum leptin than in individuals on the vegetarian diet, independent of age [115]. However, another study measuring serum leptin levels in over 50,000 healthy participants reported a positive correlation with consuming a 'Western' diet, at least in the $5^{\text {th }}$ quintile of the study population [116]. Other studies have not observed an independent association between dietary intake and serum leptin levels after adjusting for energy intake, gender, age and BMI $[117,118]$. These reports illustrate the deep and complex relationship between acidogenic diets and serum leptin concentrations in humans.

Physiological acidosis may indirectly influence leptin activity through cortisol signaling in obesity which is a condition predicted to be associated with dysregulated acidbase balance [34]. As discussed previously, acid-base status affects cortisol levels [41]. In turn, cortisol stimulates synthesis and secretion of leptin directly from adipocytes [119]. Plasma leptin concentrations are positively correlated to body fat mass in humans [120,121]. Leptin has been shown to negatively regulate cortisol levels in healthy mice and humans [122-125], implicating leptin as an antiobesity factor. In humans, leptin attenuation of cortisol appears to be a greater factor in females [124]. Serum leptin levels are paradoxically high, however, in obese individuals. This phenomenon is likely due to an acquired leptin signaling resistance that eventually occurs in the obese state [126]. On average, plasma leptin concentrations are 10 times higher in obese individuals compared to those of lean individuals $[127,128]$.

Elevated plasma leptin levels in obesity may contribute to cancer incidence [129]. Leptin has been implicated as a functional component of mammary carcinoma in wildtype p53 deficient mice [130]. Epidemiological, animal, and in vitro studies have demonstrated that leptin is associated with breast cancer, prostate cancer, gynecological cancers, gastrointestinal cancers, and leukemia [131-133]. Leptin has numerous molecular targets allowing for a multifunctional effect. Leptin functions as a mitogen and is known to stimulate breast tumor cells, prostate tumor cell lines, as well as colonic and hepatic cells. Leptin signaling is most likely to activate the mitogen-activated protein kinase (MAPK) pathway through binding of $\mathrm{Ob}-\mathrm{Rb}$ leptin receptor [131-138]. Leptin may also enhance cell proliferation through protein kinase $\mathrm{C}$ alpha $(\mathrm{PKC}-\alpha)$ $[139,140]$. Leptin has been shown to bind the estrogen receptor and stimulate estrogen biosynthesis by induction of aromatase activity [141,142]. Other cancer-permissive functional activities of leptin include promotion of angiogenesis [143-145], apoptosis [146], and cellular migration [147].

\section{Adiponectin}

Acid-base balance may play a role in modulating serum levels of adipokine hormone adiponectin. Adiponectin regulates multiple metabolic processes and is expressed exclusively in mature adipocytes and circulates in the plasma [148]. Numerous human and animal studies have reported a strong correlation between diet and serum adiponectin levels. Higher levels of serum adiponectin are typically associated with the 'Mediterranean' diet, known for high vegetable and fruit intake and low or moderate amounts of meat consumption. Other nutritional factors such as the amount and type of fatty acid intake are thought to influence serum adiponectin, but the mechanisms of diet-induced regulation of adiponectin regulation are not fully understood [149]. The first and only study demonstrating the role of acid-base disequilibrium in regulating serum adiponectin concentrations was an interventional trial to measure levels of serum adiponectin in healthy individuals induced with transient metabolic acidosis. Twenty healthy females completed a seven day course of oral ammonium chloride $\left(\mathrm{NH}_{4} \mathrm{Cl}\right)$, resulting in reduced serum bicarbonate and subsequent reduction in adiponectin mRNA and serum protein adiponectin. This was further confirmed in cultured adipocytes where acidosis inhibited gene transcription of adiponectin, suggesting a $\mathrm{pH}$ sensing mechanism at the cellular level may influence the regulation of adiponectin production [111].

Low serum adiponectin levels are considered to be permissive for development of cancer [3,150]. Reduced serum adiponectin levels are observed in patients with breast and gastric cancers, and simultaneously linked to dietary lifestyle $[151,152]$. Higher serum adiponectin may be protective against cancer as an anti-proliferative through direct binding of other growth factors, such as platelet derived growth factor-BB (PDGF-BB), heparinbinding epidermal growth factor-like growth factor (HBEGF), and basic fibroblast growth factor (basic FGF), hence restricting bioavailability [153]. This was demonstrated in a mouse study where adiponectin was shown to slow tumor growth through its inhibitory effect on tumor neovascularization [154].

In addition to its interference with proliferative signaling, adiponectin mediates its regulatory effects through two receptors, AdipoR1 and AdipoR2 [155]. Signaling through these receptors stimulates the activity of adenosine monophosphate-activated protein (AMP-k) kinase and peroxisome proliferator-activated receptor alpha (PPAR $\alpha)$ which drives glucose uptake and fatty acid oxidation. Through this mechanism, coupled with AdipoR1 receptor association with the insulin receptor, adiponectin is proposed to enhance signal transduction to promote insulin sensitivity [156]. Although a greater understanding is necessary, there is evidence suggesting 
acid-base status maintained through dietary intake could promote carcinogenesis or tumor progression through dysregulated adiponectin signaling.

\section{Lactic acid}

A very recent discussion about the role of diet-induced acidosis and pathophysiology introduces the hypothesis that persistent acidogenic or 'Western' diets lead to latent or low-grade metabolic acidosis, subsequent acidbase balance disequilibrium, and production of lactic acid at the cellular level. These events appear to be critical upstream precursors to a host of ill-conditions, diseases, and ageing. The premise further explains that increased $\left[\mathrm{H}^{+}\right]$accumulates persistently in the mitochondrial matrix without contributing to ATP production. This dynamic is theorized to inhibit mitochondrial energy production (MEP) through inhibition of the TCA cycle. MEP inhibition results in the diversion of electrons away from completion of the electron transport chain and toward the reduction of oxygen $\left(\mathrm{O}_{2}\right)$ into reactive oxygen species (ROS) such as free radical oxygen species or peroxides [34,157]. As this cycle continues, vulnerable cells develop a reduced capacity to restore homeostatic balance and are subject to increased intracellular oxidative stress.

The oxidative stress generated by ROS has multiple effects causing damage to cellular and organelle membranes, sulphydryl groups in proteins, and cross-linking or fragmenting ribonucleoproteins and DNA. DNA mutagenesis through persistent oxidative stress is generally accepted as a major mechanism behind carcinogenesis and cancer progression [158]. Oxidative DNA damage has been associated with breast cancer $[159,160]$, hepatocellular carcinoma and liver cancer [161,162], and prostate cancer [163-165]. Oxidative stress in correlation with obesity can manifest and have significant pathogenic effects within the first two decades of life [166]. Although oxidative stress can be measured directly and indirectly through various methods, it is far more difficult to differentiate between acidogenic diet-induced and endogenous ROS production coupled with antioxidant status and other molecular factors that may impact oxidative steady state [167].

\section{Osteoclast activation}

Although not fully understood, the long-term effect of diet-induced acidosis is considered to have an impact on bone osteoclasts [28]. Serum $\left[\mathrm{HCO}_{3}^{-}\right]$concentrations may only partially account for neutralization of acidity, and may be supplemented further by alkaline stores from the soft tissue and bone [168]. Osteoclastic resorption of minerals is a proposed mechanism in buffering systemic acidosis $[169,170]$. In vitro findings demonstrating the mechanisms of excess $\left[\mathrm{H}^{+}\right]$on bone tissue is the most reliable evidence currently driving the concept of compensatory buffering through acidosis-induced bone resorption. In cultured osteoclasts, lower $\mathrm{pH}$ conditions induce the breaking up of mineralized bone tissue matrix [171-175]. Bicarbonate $\left[\mathrm{HCO}_{3}^{-}\right]$deficiency may be sufficient to acidify media and promote net $\left[\mathrm{H}^{+}\right]$influx into bone [176], and appears to be necessary (not just reduced $\mathrm{pH}$ conditions which could be induced by respiratory acidosis) to stimulate calcium $\left[\mathrm{Ca}_{2}^{+}\right]$efflux from bone [177].

Stimulation of osteoclastic resorption by diet-induced acidosis is mediated through receptor activator of $\mathrm{NFKB}$ ligand (RANKL) signaling [178]. RANKL signaling is known to promote osteoclast differentiation and activates various mitogenic pathways that are frequently operational in tumor cells, including p38, MAPK, AP-1, c-Jun, and Akt/PKB [179-182]. RANKL expression has also been observed in lymphoid tissue, skeletal muscle, thymus, liver, colon, intestine, heart, brain, and the adrenal and mammary glands [183]. RANKL signaling has been shown in mouse models to promote tumorigenesis in breast and lung tissue [184]. It is unknown, however, if systemic acidosis induces RANKL activity in other cell types besides osteoclasts.

One of the strongest RANK-stimulated transcription factors in osteoclasts is the nuclear factor of activated T-cells (NFATc1) protein $[185,186]$. Once exposed to extracellular acidic $\mathrm{pH}$, cytosolic $\left[\mathrm{Ca}_{2}^{+}\right]$stores in osteoclasts increase intracellular localization of nuclear transcription factor NFATc1 through calcineurin signaling. The ovarian cancer G-protein coupled proton-sensing receptor (OGR1), which is induced during osteoclast differentiation, is thought of as the primary mediator between acidosis and NFATc1 activation. Calcineurin signaling is not required however, to maintain NFATc1 activation under extracellular acidic conditions and NFATc1 activity is reversed by extracellular alkaline conditions, suggesting that acidosis directly prevents NFATc1 inactivation by kinases [187]. NFATc1 has many functions in cancer [188] and has been linked to regulation of the c-Myc oncogene [189-193]. Although the link between acidosis and RANK/NFATc1 mediated carcinogenesis or tumor promotion is not established, chronic activation of these factors through a dietary induced state of dysregulated acid-base status may contribute to cancer risk.

\section{Conclusion}

This work examines the potential for cancer risk or tumor promoting consequences of diet-induced acidosis. Although protein is a major factor involved in promoting endogenous acid production, it should be made clear that attenuation of protein consumption is not a recommended dietary strategy for attaining improved acid- 
base balance. There is scientific evidence supporting the concept that appropriate alkali supplementation in the form of fruits and vegetables serves aptly to neutralize excess $\left[\mathrm{H}^{+}\right]$produced from protein metabolism $[34,194]$. The analysis provided discusses how diet-induced acidosis is a potential upstream and indirect trigger in a multifactorial cascade of molecular events associated with carcinogenesis. There is limited evidence to suggest that dietary acidosis alone is sufficient in increasing cancer risk, but it may function in concert with other factors associated with cancer risk. Obesity or metabolic syndrome, which effect glucocorticoid and adipokine profiles and are often linked to insulin resistance and the pro-inflammatory state, could also serve as significant factors as they are associated with both acidogenic or 'Western' diet [34] and cancer risk [3].

In conclusion, there are numerous systemic pathways affected by diet-induced acidosis that may be cancer promoting, but a causal role is poorly defined. Moreover, the contribution of diet-induced acidosis in driving carcinogenesis would be difficult to measure especially since the effects appear to accumulate for a long period of time. Nonetheless, exploring the role of dietary induced acidosis involvement in molecular pathways that promote carcinogenesis will raise new questions and foster ideas to improve our understanding on the role of acid-base balance in human disease.

\section{Abbreviations}

IGF-1: Insulin growth factor; GLUT: Glucose transporter; IDO: Indoleamine 2,3dioxygenase; TDO: 2,3-dioxygenase; APC: Antigen presenting cell; AHR: Aryl hydrocarbon receptor; ROS: Reactive oxygen species; CKD: Chronic kidney disease; BMI: Body mass index; PDGF-BB: Platelet derived growth factor-BB; OGR1: Ovarian cancer G-protein coupled proton-sensing receptor; NFATc1: Nuclear factor of activated T-cells; AMP-k: Adenosine monophosphate-activated protein kinase; PPARa: Peroxisome proliferatoractivated receptor alpha; MEP: Mitochondrial energy production; MAPK: Mitogen-activated protein kinase; 11ßHSD2: 11ß-hydroxysteroid dehydrogenase 2; HB EGF: Heparin-binding epidermal growth factor-like growth factor; RANKL: Receptor activator of NFKB ligand; OGR1: Ovarian cancer G-protein coupled proton-sensing receptor; NFATc1: Nuclear factor of activated T-cells; AMP-k: Adenosine monophosphate-activated protein kinase: PPARa: Peroxisome proliferator-activated receptor alpha; MEP: Mitochondrial energy production; MAPK: Mitogen-activated protein kinase; 11ßHSD2: 11ßhydroxysteroid dehydrogenase 2; AICR: American Institute for Cancer Research.

\section{Competing interests}

The author declares that he has no competing interests.

\section{Authors' contributions}

IR conceived and drafted the manuscript in its entirety and approves the final manuscript.

\section{Acknowledgements}

National Centers for Complementary and Alternative Medicine, $\mathrm{NIH}$ grant K01AT004678.

Received: 24 April 2012 Accepted: 27 July 2012

Published: 1 August 2012

\section{References}

1. Cancer Facts and Figures. In American Cancer Society. Edited by Society AC. Atlanta:; 2004. http://www.cancer.org/acs/groups/content/ @epidemiologysurveilance/documents/document/acspc-028323.pdf.

2. Calle EE, Kaaks R: Overweight, obesity and cancer: epidemiological evidence and proposed mechanisms. Nat Rev Cancer 2004, 4(8):579-591.

3. Hursting SD, Berger NA: Energy balance, host-related factors, and cancer progression. J Clin Oncol 2010, 28(26):4058-4065.

4. Research WCRFAlfC: Food, Nutrition, and Physical Activity, and the Prevention of Cancer: A Global Perspective. In. Washington DC: AICR; 2007.

5. Kato Y, Lambert CA, Colige AC, Mineur P, Noel A, Frankenne F, Foidart JM, Baba M, Hata R, Miyazaki K, et al: Acidic extracellular pH induces matrix metalloproteinase-9 expression in mouse metastatic melanoma cells through the phospholipase D-mitogen-activated protein kinase signaling. J Biol Chem 2005, 280(12):10938-10944.

6. Kato Y, Ozawa S, Tsukuda M, Kubota E, Miyazaki K, St-Pierre Y, Hata R: Acidic extracellular $\mathrm{pH}$ increases calcium influx-triggered phospholipase $\mathrm{D}$ activity along with acidic sphingomyelinase activation to induce matrix metalloproteinase-9 expression in mouse metastatic melanoma. FEBS J 2007, 274(12):3171-3183

7. Martinez-Zaguilan R, Seftor EA, Seftor RE, Chu YW, Gillies RJ, Hendrix MJ: Acidic $\mathrm{pH}$ enhances the invasive behavior of human melanoma cells. Clin Exp Metastasis 1996, 14(2):176-186.

8. Moellering RE, Black KC, Krishnamurty C, Baggett BK, Stafford P, Rain M, Gatenby RA, Gillies RJ: Acid treatment of melanoma cells selects for invasive phenotypes. Clin Exp Metastasis 2008, 25(4):411-425.

9. Rofstad EK, Mathiesen B, Kindem K, Galappathi K: Acidic extracellular pH promotes experimental metastasis of human melanoma cells in athymic nude mice. Cancer Res 2006, 66(13):6699-6707.

10. Rozhin J, Sameni M, Ziegler G, Sloane BF: Pericellular pH affects distribution and secretion of cathepsin B in malignant cells. Cancer Res 1994, 54(24):6517-6525.

11. Shi Q, Le X, Wang B, Abbruzzese JL, Xiong Q, He Y, Xie K: Regulation of vascular endothelial growth factor expression by acidosis in human cancer cells. Oncogene 2001, 20(28):3751-3756.

12. Welbourne TC, Francoeur D: Influence of aldosterone on renal ammonia production. Am J Physiol 1977, 233(1):E56-E60.

13. $\mathrm{Xu} \mathrm{L}$, Fidler IJ: Acidic $\mathrm{pH}$-induced elevation in interleukin 8 expression by human ovarian carcinoma cells. Cancer Res 2000, 60(16):4610-4616.

14. Xu L, Fukumura D, Jain RK: Acidic extracellular pH induces vascular endothelial growth factor (VEGF) in human glioblastoma cells via ERK1/2 MAPK signaling pathway: mechanism of low pH-induced VEGF. J Biol Chem 2002, 277(13):11368-11374.

15. Schornack PA, Gillies RJ: Contributions of cell metabolism and $\mathrm{H}$ + diffusion to the acidic pH of tumors. Neoplasia 2003, 5(2):135-145.

16. Cordain L, Eaton SB, Sebastian A, Mann N, Lindeberg S, Watkins BA, O'Keefe JH, Brand-Miller J: Origins and evolution of the Western diet: health implications for the 21st century. Am J Clin Nutr 2005, 81(2):341-354.

17. Halperin ML: Metabolism and acid-base physiology. Artif Organs 1982, 6(4):357-362.

18. Kleinman J, Lemann J Jr: Acid Production. In Clinical disorders of fluid and electrolyte metabolism. 4th edition. Edited by Maxwell M, Kleeman C, Narins R. New York: McGraw Hill; 1987:159-173.

19. Frassetto LA, Morris RC Jr, Sebastian A: Dietary sodium chloride intake independently predicts the degree of hyperchloremic metabolic acidosis in healthy humans consuming a net acid-producing diet. Am J Physiol Renal Physiol 2007, 293(2):F521-F525.

20. Frings-Meuthen P, Baecker N, Heer M: Low-grade metabolic acidosis may be the cause of sodium chloride-induced exaggerated bone resorption. J Bone Miner Res 2008, 23(4):517-524.

21. Frassetto LA, Todd KM, Morris RC Jr, Sebastian A: Estimation of net endogenous noncarbonic acid production in humans from diet potassium and protein contents. Am J Clin Nutr 1998, 68(3):576-583.

22. Remer T, Manz F: Paleolithic diet, sweet potato eaters, and potential renal acid load. Am J Clin Nutr 2003, 78(4):802-803. author reply 803-804.

23. Remer T, Manz F: Estimation of the renal net acid excretion by adults consuming diets containing variable amounts of protein. Am J Clin Nutr 1994, 59(6):1356-1361.

24. Remer T, Manz F: Dietary protein as a modulator of the renal net acid excretion capacity: Evidence that an increased protein intake improves 
the capability of the kidney to excrete ammonium. J Nutr Biochem 1995, 6:431-437.

25. Frassetto L, Morris RC Jr: Sellmeyer DE, Todd K, Sebastian A: Diet, evolution and aging-the pathophysiologic effects of the postagricultural inversion of the potassium-to-sodium and base-to-chloride ratios in the human diet. Eur J Nutr 2001, 40(5):200-213.

26. Frassetto $L$, Sebastian A: Age and systemic acid-base equilibrium: analysis of published data. J Gerontol A Biol Sci Med Sci 1996, 51(1):B91-B99.

27. Frassetto LA, Morris RC Jr, Sebastian A: Effect of age on blood acid-base composition in adult humans: role of age-related renal functional decline. Am J Physiol 1996, 271(6 Pt 2):F1114-F1122.

28. Pizzorno J, Frassetto LA, Katzinger J: Diet-induced acidosis: is it real and clinically relevant? Br J Nutr 2010, 103(8):1185-1194.

29. Kurtz I, Maher T, Hulter HN, Schambelan M, Sebastian A: Effect of diet on plasma acid-base composition in normal humans. Kidney Int 1983, 24(5):670-680.

30. Sebastian A, Frassetto LA, Sellmeyer DE, Merriam RL, Morris RC Jr: Estimation of the net acid load of the diet of ancestral preagricultural Homo sapiens and their hominid ancestors. Am J Clin Nutr 2002, 76(6):1308-1316

31. Vormann J, Goedeke T: Latent acidosis: acidity as a cause for chronic diseases [Latente Azidose: Übersäuerung als Ursache chronischer Erkrankungen]. Schewiz Zschr Ganszheits Medizin 2002, 2:90-96.

32. Gluck SL: Acid-base. Lancet 1998, 352(9126):474-479.

33. Kraut JA, Madias NE: Metabolic acidosis: pathophysiology, diagnosis and management. Nat Rev Nephrol 2010, 6(5):274-285.

34. Berkemeyer S: Acid-base balance and weight gain: are there crucial links via protein and organic acids in understanding obesity? Med Hypotheses 2009, 73(3):347-356

35. Hwang JJ, Curthoys NP: Effect of acute alterations in acid-base balance on rat renal glutaminase and phosphoenolpyruvate carboxykinase gene expression. J Biol Chem 1991, 266(15):9392-9396.

36. Karim Z, Attmane-Elakeb A, Bichara M: Renal handling of $\mathrm{NH} 4+$ in relation to the control of acid-base balance by the kidney. J Nephrol 2002, 15(Suppl 5):S128-S134

37. Welbourne TC: Acidosis activation of the pituitary-adrenal-renal glutaminase I axis. Endocrinology 1976, 99(4):1071-1079.

38. Espino L, Suarez ML, Santamarina G, Goicoa A, Fidalgo LE: Effects of dietary cation-anion difference on blood cortisol and ACTH levels in reproducing ewes. J Vet Med A Physiol Pathol Clin Med 2005, 52(1):8-12.

39. Gibson EL, Checkley S, Papadopoulos A, Poon L, Daley S, Wardle J: Increased salivary cortisol reliably induced by a protein-rich midday meal. Psychosom Med 1999, 61(2):214-224

40. Slag MF, Ahmad M, Gannon MC, Nuttall FQ: Meal stimulation of cortiso secretion: a protein induced effect. Metabolism 1981, 30(11):1104-1108.

41. Maurer M, Riesen W, Muser J, Hulter HN, Krapf R: Neutralization of Western diet inhibits bone resorption independently of $\mathrm{K}$ intake and reduces cortisol secretion in humans. Am J Physiol Renal Physiol 2003, 284(1):F32-F40.

42. Lemmens SG, Born JM, Martens EA, Martens MJ, Westerterp-Plantenga MS: Influence of consumption of a high-protein vs. high-carbohydrate meal on the physiological cortisol and psychological mood response in men and women. PLoS One 2011, 6(2):e16826.

43. Martens MJ, Rutters F, Lemmens SG, Born JM, Westerterp-Plantenga MS: Effects of single macronutrients on serum cortisol concentrations in normal weight men. Physiol Behav 2010, 101(5):563-567.

44. Vicennati V, Ceroni L, Gagliardi L, Gambineri A, Pasquali R: Comment: response of the hypothalamic-pituitary-adrenocortical axis to highprotein/fat and high-carbohydrate meals in women with different obesity phenotypes. J Clin Endocrinol Metab 2002, 87(8):3984-3988.

45. Zhao XY, Malloy PJ, Krishnan AV, Swami S, Navone NM, Peehl DM, Feldman D: Glucocorticoids can promote androgen-independent growth of prostate cancer cells through a mutated androgen receptor. Nat Med 2000, 6(6):703-706.

46. Goya L, Maiyar AC, Ge Y, Firestone GL: Glucocorticoids induce a G1/G0 cell cycle arrest of Con8 rat mammary tumor cells that is synchronously reversed by steroid withdrawal or addition of transforming growth factor-alpha. Mol Endocrinol 1993, 7(9):1121-1132.

47. Lippman M, Bolan G, Huff K: The effects of glucocorticoids and progesterone on hormone-responsive human breast cancer in long-term tissue culture. Cancer Res 1976, 36(12):4602-4609.
48. Wan $Y$, Nordeen SK: Overlapping but distinct gene regulation profiles by glucocorticoids and progestins in human breast cancer cells. Mol Endocrinol 2002, 16(6):1204-1214.

49. Guyre PM, Girard MT, Morganelli PM, Manganiello PD: Glucocorticoid effects on the production and actions of immune cytokines. J Steroid Biochem 1988, 30(1-6):89-93.

50. Oxenkrug GF: Genetic and hormonal regulation of tryptophan kynurenine metabolism: implications for vascular cognitive impairment, major depressive disorder, and aging. Ann N Y Acad Sci 2007, 1122:35-49.

51. Katz JB, Muller AJ, Prendergast GC: Indoleamine 2,3-dioxygenase in T-cell tolerance and tumoral immune escape. Immunol Rev 2008, 222:206-221.

52. Opitz CA, Litzenburger UM, Sahm F, Ott M, Tritschler I, Trump S, Schumacher T, Jestaedt L, Schrenk D, Weller M, et al: An endogenous tumour-promoting ligand of the human aryl hydrocarbon receptor. Nature 2011, 478(7368):197-203.

53. Prendergast GC, Metz R, Muller AJ: Towards a genetic definition of cancerassociated inflammation: role of the IDO pathway. Am J Pathol 2011, 176(5):2082-2087

54. Fallarino F, Gizzi S, Mosci P, Grohmann U, Puccetti P: Tryptophan catabolism in IDO + plasmacytoid dendritic cells. Curr Drug Metab 2007, 8(3):209-216.

55. Apetoh L, Quintana FJ, Pot C, Joller N, Xiao S, Kumar D, Burns EJ, Sherr DH, Weiner $\mathrm{HL}$, Kuchroo VK: The aryl hydrocarbon receptor interacts with cMaf to promote the differentiation of type 1 regulatory $T$ cells induced by IL-27. Nat Immunol 2010, 11(9):854-861.

56. Quintana FJ, Basso AS, Iglesias AH, Korn T, Farez MF, Bettelli E, Caccamo M, Oukka M, Weiner HL: Control of T(reg) and $T(H) 17$ cell differentiation by the aryl hydrocarbon receptor. Nature 2008, 453(7191):65-71.

57. Quintana FJ, Murugaiyan G, Farez MF, Mitsdoerffer M, Tukpah AM, Burns EJ Weiner HL: An endogenous aryl hydrocarbon receptor ligand acts on dendritic cells and T cells to suppress experimental autoimmune encephalomyelitis. Proc Natl Acad Sci U S A 2010, 107(48):20768-20773.

58. Miller LK, Kral JG, Strain GW, Zumoff B: Differential binding of dexamethasone to ammonium sulfate precipitates of human adipose tissue cytosols. Steroids 1987, 49(6):507-522.

59. Rebuffe-Scrive M, Bronnegard M, Nilsson A, Eldh J, Gustafsson JA, Bjorntorp P: Steroid hormone receptors in human adipose tissues. J Clin Endocrinol Metab 1990, 71(5):1215-1219.

60. Bujalska IJ, Kumar S, Stewart PM: Does central obesity reflect "Cushing's disease of the omentum"? Lancet 1997, 349(9060):1210-1213.

61. Buren J, Liu HX, Jensen J, Eriksson JW: Dexamethasone impairs insulin signalling and glucose transport by depletion of insulin receptor substrate-1, phosphatidylinositol 3-kinase and protein kinase B in primary cultured rat adipocytes. Eur J Endocrinol 2002, 146(3):419-429.

62. Carter-Su C, Okamoto K: Effect of glucocorticoids on hexose transport in rat adipocytes. Evidence for decreased transporters in the plasma membrane. J Biol Chem 1985, 260(20):11091-11098.

63. Fried SK, Russell CD, Grauso NL, Brolin RE: Lipoprotein lipase regulation by insulin and glucocorticoid in subcutaneous and omental adipose tissues of obese women and men. J Clin Invest 1993, 92(5):2191-2198.

64. Livingston JN, Lockwood DH: Effect of glucocorticoids on the glucose transport system of isolated fat cells. J Biol Chem 1975, 250(21):8353-8360.

65. Sakoda H, Ogihara T, Anai M, Funaki M, Inukai K, Katagiri H, Fukushima $Y$, Onishi $Y$, Ono $H$, Fujishiro $M$, et al: Dexamethasone-induced insulin resistance in 3T3-L1 adipocytes is due to inhibition of glucose transport rather than insulin signal transduction. Diabetes 2000, 49(10):1700-1708.

66. Turnbow MA, Smith LK, Garner CW: The oxazolidinedione CP-92,768-2 partially protects insulin receptor substrate-1 from dexamethasone downregulation in 3T3-L1 adipocytes. Endocrinology 1995, 136(4):1450-1458.

67. Frayn KN: Adipose tissue and the insulin resistance syndrome. Proc Nutr Soc 2001, 60(3):375-380.

68. Andrews RC, Walker BR: Glucocorticoids and insulin resistance: old hormones, new targets. Clin Sci (Lond) 1999, 96(5):513-523.

69. Qi D, Rodrigues B: Glucocorticoids produce whole body insulin resistance with changes in cardiac metabolism. Am J Physiol Endocrinol Metab 2007, 292(3):E654-E667.

70. Reynolds RM, Walker BR: Human insulin resistance: the role of glucocorticoids. Diabetes Obes Metab 2003, 5(1):5-12

71. Everhart J, Wright D: Diabetes mellitus as a risk factor for pancreatic cancer. A meta-analysis. JAMA 1995, 273(20):1605-1609. 
72. Fair AM, Dai Q, Shu XO, Matthews CE, Yu H, Jin F, Gao YT, Zheng W: Energy balance, insulin resistance biomarkers, and breast cancer risk Cancer Detect Prev 2007, 31(3):214-219.

73. Giovannucci E: Insulin and colon cancer. Cancer Causes Control 1995 6(2):164-179.

74. McKeown-Eyssen G: Epidemiology of colorectal cancer revisited: are serum triglycerides and/or plasma glucose associated with risk? Cancer Epidemiol Biomarkers Prev 1994, 3(8):687-695.

75. Pisani P: Hyper-insulinaemia and cancer, meta-analyses of epidemiological studies. Arch Physiol Biochem 2008, 114(1):63-70.

76. Weiderpass E, Partanen T, Kaaks R, Vainio H, Porta M, Kauppinen T, Ojajarvi A, Boffetta P, Malats N: Occurrence, trends and environment etiology of pancreatic cancer. Scand J Work Environ Health 1998, 24(3):165-174.

77. Kaaks R, Lukanova A, Kurzer MS: Obesity, endogenous hormones, and endometrial cancer risk: a synthetic review. Cancer Epidemiol Biomarkers Prev 2002, 11(12):1531-1543.

78. Wideroff L, Gridley G, Mellemkjaer L, Chow WH, Linet M, Keehn S, Borch-Johnsen $\mathrm{K}$, Olsen $\mathrm{JH}$ : Cancer incidence in a population-based cohort of patients hospitalized with diabetes mellitus in Denmark. J Natl Cancer Inst 1997, 89(18):1360-1365.

79. Kaaks R: Nutrition, hormones, and breast cancer: is insulin the missing link? Cancer Causes Control 1996, 7(6):605-625.

80. Stoll BA: Western nutrition and the insulin resistance syndrome: a link to breast cancer. Eur J Clin Nutr 1999, 53(2):83-87.

81. Gunter MJ, Hoover DR, Yu H, Wassertheil-Smoller S, Rohan TE, Manson JE, Li J Ho GY, Xue X, Anderson GL, et al: Insulin, insulin-like growth factor-l, and risk of breast cancer in postmenopausal women. J Natl Cancer Inst 2009, 101(1):48-60.

82. Irwin ML, Duggan C, Wang CY, Smith AW, McTiernan A, Baumgartner RN Baumgartner KB, Bernstein L, Ballard-Barbash R: Fasting C-peptide levels and death resulting from all causes and breast cancer: the health, eating, activity, and lifestyle study. J Clin Oncol 2011, 29(1):47-53.

83. Kabat GC, Kim M, Caan BJ, Chlebowski RT, Gunter MJ, Ho GY, Rodriguez BL, Shikany JM, Strickler HD, Vitolins MZ, et al: Repeated measures of serum glucose and insulin in relation to postmenopausal breast cancer. Int J Cancer 2009, 125(11):2704-2710.

84. Tran T, Medline A, Bruce WR: Insulin promotion of colon tumors in rats. Cancer Epidemiol Biomarkers Prev 1996, 5(12):1013-1015.

85. Fierz Y, Novosyadlyy R, Vijayakumar A, Yakar S, LeRoith D: Insulin-sensitizing therapy attenuates type 2 diabetes-mediated mammary tumor progression. Diabetes 2010, 59(3):686-693.

86. Novosyadlyy R, Lann DE, Vijayakumar A, Rowzee A, Lazzarino DA, Fierz Y, Carboni JM, Gottardis MM, Pennisi PA, Molinolo AA, et al: Insulinmediated acceleration of breast cancer development and progression in a nonobese model of type 2 diabetes. Cancer Res 2010, 70(2): $741-751$.

87. Heuson JC, Legros N: Influence of insulin deprivation on growth of the 7,12-dimethylbenz(a)anthracene-induced mammary carcinoma in rats subjected to alloxan diabetes and food restriction. Cancer Res 1972, 32(2):226-232

88. Belfiore A, Malaguarnera R: Insulin receptor and cancer. Endocr Relat Cancer 2011, 18(4):R125-R147.

89. Vigneri $P$, Frasca F, Sciacca L, Frittitta L, Vigneri R: Obesity and cancer. Nutr Metab Cardiovasc Dis 2006, 16(1):1-7.

90. Brungger M, Hulter HN, Krapf R: Effect of chronic metabolic acidosis on thyroid hormone homeostasis in humans. Am J Physiol 1997, 272(5 Pt 2):F648-F653.

91. Challa A, Chan W, Krieg RJ Jr, Thabet MA, Liu F, Hintz RL, Chan JC: Effect of metabolic acidosis on the expression of insulin-like growth factor and growth hormone receptor. Kidney Int 1993, 44(6):1224-1227.

92. Clemmons DR, Klibanski A, Underwood LE, McArthur JW, Ridgway EC, Beitins IZ, Van Wyk JJ: Reduction of plasma immunoreactive somatomedin C during fasting in humans. J Clin Endocrinol Metab 1981, 53(6):1247-1250.

93. Isley WL, Underwood LE, Clemmons DR: Dietary components that regulate serum somatomedin-C concentrations in humans. J Clin Invest 1983, 71(2):175-182

94. Isley WL, Underwood LE, Clemmons DR: Changes in plasma somatomedin- $C$ in response to ingestion of diets with variable protein and energy content. JPEN J Parenter Enteral Nutr 1984, 8(4):407-411.

95. Caldas A, Fontoura M: Effects of chronic metabolic acidosis (CMA) in 24-hour growth hormone secretion. J Am Soc Nephrol 1993, 4:828-828.
96. Cadogan J, Eastell R, Jones N, Barker ME: Milk intake and bone mineral acquisition in adolescent girls: randomised, controlled intervention trial. BMJ 1997, 315(7118):1255-1260.

97. Fontana L, Klein S, Holloszy JO: Long-term low-protein, low-calorie diet and endurance exercise modulate metabolic factors associated with cancer risk. Am J Clin Nutr 2006, 84(6):1456-1462.

98. Heaney RP, McCarron DA, Dawson-Hughes B, Oparil S, Berga SL, Stern JS, Barr SI, Rosen CJ: Dietary changes favorably affect bone remodeling in older adults. J Am Diet Assoc 1999, 99(10):1228-1233.

99. Schurch MA, Rizzoli R, Slosman D, Vadas L, Vergnaud P, Bonjour JP: Protein supplements increase serum insulin-like growth factor-I levels and attenuate proximal femur bone loss in patients with recent hip fracture. A randomized, double-blind, placebo-controlled trial. Ann Intern Med 1998, 128(10):801-809.

100. Giovannucci E, Pollak M, Liu Y, Platz EA, Majeed N, Rimm EB, Willett WC: Nutritional predictors of insulin-like growth factor I and their relationships to cancer in men. Cancer Epidemiol Biomarkers Prev 2003, 12(2):84-89.

101. Cohen P, Peehl DM, Rosenfeld RG: The IGF axis in the prostate. Horm Metab Res 1994, 26(2):81-84.

102. LeRoith D, Baserga R, Helman L, Roberts CT Jr: Insulin-like growth factors and cancer. Ann Intern Med 1995, 122(1):54-59.

103. Pollak MN: Endocrine effects of IGF-I on normal and transformed breast epithelial cells: potential relevance to strategies for breast cancer treatment and prevention. Breast Cancer Res Treat 1998, 47(3):209-217.

104. Chan JM, Stampfer MJ, Giovannucci E, Gann PH, Ma J, Wilkinson P, Hennekens $\mathrm{CH}$, Pollak M: Plasma insulin-like growth factor-I and prostate cancer risk: a prospective study. Science 1998, 279(5350):563-566.

105. Mantzoros CS, Tzonou A, Signorello LB, Stampfer M, Trichopoulos D, Adami HO: Insulin-like growth factor 1 in relation to prostate cancer and benign prostatic hyperplasia. Br J Cancer 1997, 76(9):1115-1118.

106. Kaaks R, Toniolo P, Akhmedkhanov A, Lukanova A, Biessy C, Dechaud H, Rinaldi S, Zeleniuch-Jacquotte A, Shore RE, Riboli E: Serum C-peptide, insulin-like growth factor (IGF)-I, IGF-binding proteins, and colorectal cancer risk in women. J Nat/ Cancer Inst 2000, 92(19):1592-1600.

107. Ma J, Giovannucci E, Pollak M, Chan JM, Gaziano JM, Willett W, Stampfer MJ: Milk intake, circulating levels of insulin-like growth factor-l, and risk of colorectal cancer in men. J Natl Cancer Inst 2001, 93(17):1330-1336.

108. Ma J, Pollak MN, Giovannucci E, Chan JM, Tao Y, Hennekens CH, Stampfer MJ: Prospective study of colorectal cancer risk in men and plasma levels of insulin-like growth factor (IGF)-I and IGF-binding protein-3. J Nat/ Cancer Inst 1999, 91(7):620-625.

109. Hankinson SE, Willett WC, Colditz GA, Hunter DJ, Michaud DS, Deroo B, Rosner B, Speizer FE, Pollak M: Circulating concentrations of insulin-like growth factor-I and risk of breast cancer. Lancet 1998, 351(9113):1393-1396.

110. Zhang Y, Proenca R, Maffei M, Barone M, Leopold L, Friedman JM: Positional cloning of the mouse obese gene and its human homologue. Nature 1994, 372(6505):425-432.

111. Disthabanchong S, Niticharoenpong K, Radinahamed P, Stitchantrakul W, Ongphiphadhanakul B, Hongeng S: Metabolic acidosis lowers circulating adiponectin through inhibition of adiponectin gene transcription. Nephrol Dial Transplant 2010, 26(2):592-598.

112. Teta D, Bevington A, Brown J, Pawluczyk I, Harris K, Walls J: Acidosis downregulates leptin production from cultured adipocytes through a glucose transport-dependent post-transcriptional mechanism. J Am Soc Nephrol 2003, 14(9):2248-2254.

113. Teta D, Bevington A, Brown J, Throssell D, Harris KP, Walls J: Effects of acidosis on leptin secretion from 3T3-L1 adipocytes and on serum leptin in the uraemic rat. Clin Sci (Lond) 1999, 97(3):363-368.

114. Zheng F, Qiu X, Yin S, Li Y: Changes in serum leptin levels in chronic renal failure patients with metabolic acidosis. J Ren Nutr 2001, 11(4):207-211.

115. Winnicki M, Somers VK, Accurso V, Phillips BG, Puato M, Palatini P, Pauletto P: Fish-rich diet, leptin, and body mass. Circulation 2002, 106(3):289-291.

116. Fung T, Rimm EB, Spiegelman D, Rifai N, Tofler GH, Willett WC, Hu FB: Association between dietary patterns and plasma biomarkers of obesity and cardiovascular disease risk. Am J Clin Nutr 2001, 73(1):61-67

117. Chu NF, Stampfer MJ, Spiegelman D, Rifai N, Hotamisligil GS, Rimm EB: Dietary and lifestyle factors in relation to plasma leptin concentrations among normal weight and overweight men. Int J Obes Relat Metab Disord 2001, 25(1):106-114 
118. Ganji V, Kafai MR, McCarthy E: Serum leptin concentrations are not related to dietary patterns but are related to sex, age, body mass index, serum triacylglycerol, serum insulin, and plasma glucose in the US population. Nutr Metab (Lond) 2009, 6:3.

119. Slieker LJ, Sloop KW, Surface PL, Kriauciunas A, LaQuier F, Manetta J, Bue-Valleskey J, Stephens TW: Regulation of expression of ob mRNA and protein by glucocorticoids and CAMP. J Biol Chem 1996, 271(10):5301-5304.

120. Girard J: Is leptin the link between obesity and insulin resistance? Diabetes Metab 1997, 23(Suppl 3):16-24.

121. Kahn BB, Flier JS: Obesity and insulin resistance. J Clin Invest 2000, 106 (4):473-481.

122. Heiman ML, Ahima RS, Craft LS, Schoner B, Stephens TW, Flier JS: Leptin inhibition of the hypothalamic-pituitary-adrenal axis in response to stress. Endocrinology 1997, 138(9):3859-3863.

123. Korbonits M, Trainer PJ, Little JA, Edwards R, Kopelman PG, Besser GM, Svec F, Grossman AB: Leptin levels do not change acutely with food administration in normal or obese subjects, but are negatively correlated with pituitaryadrenal activity. Clin Endocrinol (Oxf) 1997, 46(6):751-757.

124. Remer T, Dimitriou T, Maser-Gluth C: Renal net acid excretion and plasma leptin are associated with potentially bioactive free glucocorticoids in healthy lean women. J Nutr 2008, 138(2):426S-430S.

125. Stephens TW, Basinski M, Bristow PK, Bue-Valleskey JM, Burgett SG, Craft L, Hale J, Hoffmann J, Hsiung HM, Kriauciunas A, et al: The role of neuropeptide $\mathrm{Y}$ in the antiobesity action of the obese gene product. Nature 1995, 377(6549):530-532.

126. Enriori PJ, Evans AE, Sinnayah P, Cowley MA: Leptin resistance and obesity. Obesity (Silver Spring) 2006, 14(Suppl 5):254S-258S.

127. Considine RV, Sinha MK, Heiman ML, Kriauciunas A, Stephens TW, Nyce MR, Ohannesian JP, Marco CC, McKee LJ, Bauer TL, et al: Serum immunoreactive-leptin concentrations in normal-weight and obese humans. N Engl J Med 1996, 334(5):292-295.

128. Silha JV, Krsek M, Skrha JV, Sucharda P, Nyomba BL, Murphy LJ: Plasma resistin, adiponectin and leptin levels in lean and obese subjects: correlations with insulin resistance. Eur J Endocrinol 2003, 149(4):331-335.

129. Garofalo C, Surmacz E: Leptin and cancer. J Cell Physiol 2006, 207(1):12-22.

130. Hursting SD, Perkins SN, Phang JM, Barrett JC: Diet and cancer prevention studies in p53-deficient mice. J Nutr 2001, 131(11 Suppl):3092S-3094S.

131. Rose DP, Komninou D, Stephenson GD: Obesity, adipocytokines, and insulin resistance in breast cancer. Obes Rev 2004, 5(3):153-165.

132. Somasundar P, Frankenberny KA, Skinner H, Vedula G, McFadden DW, Riggs D, Jackson B, Vangilder R, Hileman SM, Vona-Davis LC: Prostate cancer cell proliferation is influenced by leptin. J Surg Res 2004, 118(1):71-82.

133. Somasundar P, McFadden DW, Hileman SM, Vona-Davis L: Leptin is a growth factor in cancer. J Surg Res 2004, 116(2):337-349.

134. Dieudonne MN, Machinal-Quelin F, Serazin-Leroy V, Leneveu MC, Pecquery R, Giudicelli Y: Leptin mediates a proliferative response in human MCF7 breast cancer cells. Biochem Biophys Res Commun 2002, 293(1):622-628.

135. Hardwick JC, Van Den Brink GR, Offerhaus GJ, Van Deventer SJ, Peppelenbosch MP: Leptin is a growth factor for colonic epithelial cells. Gastroenterology 2001, 121(1):79-90.

136. Hu X, Juneja SC, Maihle NJ, Cleary MP: Leptin-a growth factor in normal and malignant breast cells and for normal mammary gland development. J Natl Cancer Inst 2002, 94(22):1704-1711.

137. Laud K, Gourdou I, Pessemesse L, Peyrat JP, Djiane J: Identification of leptin receptors in human breast cancer: functional activity in the T47-D breast cancer cell line. Mol Cell Endocrinol 2002, 188(1-2):219-226.

138. Wang Y, Kuropatwinski KK, White DW, Hawley TS, Hawley RG, Tartaglia LA, Baumann H: Leptin receptor action in hepatic cells. J Biol Chem 1997 272(26):16216-16223.

139. Okumura M, Yamamoto M, Sakuma H, Kojima T, Maruyama T, Jamali M, Cooper DR, Yasuda K: Leptin and high glucose stimulate cell proliferation in MCF-7 human breast cancer cells: reciprocal involvement of PKCalpha and PPAR expression. Biochim Biophys Acta 2002, 1592(2):107-116.

140. Takekoshi K, Ishii K, Nanmoku T, Shibuya S, Kawakami Y, Isobe K, Nakai T: Leptin stimulates catecholamine synthesis in a PKC-dependent manner in cultured porcine adrenal medullary chromaffin cells. Endocrinology 2001, 142(11):4861-4871.

141. Catalano S, Marsico S, Giordano C, Mauro L, Rizza P, Panno ML, Ando S: Leptin enhances, via AP-1, expression of aromatase in the MCF-7 cell line. J Biol Chem 2003, 278(31):28668-28676
142. Catalano S, Mauro L, Marsico S, Giordano C, Rizza P, Rago V, Montanaro D, Maggiolini M, Panno ML, Ando S: Leptin induces, via ERK1/ERK2 signal, functional activation of estrogen receptor alpha in MCF-7 cells. J Biol Chem 2004, 279(19):19908-19915.

143. Bouloumie A, Drexler HC, Lafontan M, Busse R: Leptin, the product of Ob gene, promotes angiogenesis. Circ Res 1998, 83(10):1059-1066.

144. Park HY, Kwon HM, Lim HJ, Hong BK, Lee JY, Park BE, Jang Y, Cho SY, Kim HS: Potential role of leptin in angiogenesis: leptin induces endothelial cell proliferation and expression of matrix metalloproteinases in vivo and in vitro. Exp Mol Med 2001, 33(2):95-102.

145. Sierra-Honigmann MR, Nath AK, Murakami C, Garcia-Cardena G, Papapetropoulos A, Sessa WC, Madge LA, Schechner JS, Schwabb MB, Polverini PJ, et al: Biological action of leptin as an angiogenic factor. Science 1998, 281(5383):1683-1686.

146. Artwohl M, Roden M, Holzenbein T, Freudenthaler A, WaldhausI W, Baumgartner-Parzer SM: Modulation by leptin of proliferation and apoptosis in vascular endothelial cells. Int J Obes Relat Metab Disord 2002, 26(4):577-580

147. Kume K, Satomura K, Nishisho S, Kitaoka E, Yamanouchi K, Tobiume S, Nagayama M: Potential role of leptin in endochondral ossification. J Histochem Cytochem 2002, 50(2):159-169.

148. Diez JJ, Iglesias P: The role of the novel adipocyte-derived hormone adiponectin in human disease. Eur J Endocrinol 2003, 148(3):293-300.

149. Reis CE, Bressan J, Alfenas RC: Effect of the diet components on adiponectin levels. Nutr Hosp 2010, 25(6):881-888.

150. Koerner A, Kratzsch J, Kiess W: Adipocytokines: leptin-the classical, resistin-the controversical, adiponectin-the promising, and more to come. Best Pract Res Clin Endocrinol Metab 2005, 19(4):525-546.

151. Ishikawa M, Kitayama J, Kazama S, Hiramatsu T, Hatano K, Nagawa H: Plasma adiponectin and gastric cancer. Clin Cancer Res 2005, 11(2 Pt 1):466-472.

152. Miyoshi $Y$, Funahashi $T$, Kihara $S$, Taguchi $T$, Tamaki $Y$, Matsuzawa $Y$, Noguchi S: Association of serum adiponectin levels with breast cancer risk. Clin Cancer Res 2003, 9(15):5699-5704

153. Wang Y, Lam KS, Xu JY, Lu G, Xu LY, Cooper GJ, Xu A: Adiponectin inhibits cell proliferation by interacting with several growth factors in an oligomerization-dependent manner. J Biol Chem 2005, 280(18):18341-18347.

154. Brakenhielm E, Veitonmaki N, Cao R, Kihara S, Matsuzawa Y, Zhivotovsky B, Funahashi T, Cao Y: Adiponectin-induced antiangiogenesis and antitumor activity involve caspase-mediated endothelial cell apoptosis. Proc Natl Acad Sci U S A 2004, 101(8):2476-2481.

155. Yamauchi T, Kamon J, Ito Y, Tsuchida A, Yokomizo T, Kita S, Sugiyama T, Miyagishi M, Hara K, Tsunoda M, et al: Cloning of adiponectin receptors that mediate antidiabetic metabolic effects. Nature 2003, 423(6941):762-769.

156. Gil-Campos M, Canete RR, Gil A: Adiponectin, the missing link in insulin resistance and obesity. Clin Nutr 2004, 23(5):963-974.

157. Berkemeyer $\mathrm{S}$ : The straight line hypothesis elaborated: case reference obesity, an argument for acidosis, oxidative stress, and disease conglomeration? Med Hypotheses 2010, 75(1):59-64.

158. Waris $G$, Ahsan $H$ : Reactive oxygen species: role in the development of cancer and various chronic conditions. J Carcinog 2006, 5:14.

159. Malins DC, Haimanot R: Major alterations in the nucleotide structure of DNA in cancer of the female breast. Cancer Res 1991, 51(19):5430-5432.

160. Malins DC, Polissar NL, Gunselman SJ: Progression of human breast cancers to the metastatic state is linked to hydroxyl radical-induced DNA damage. Proc Natl Acad Sci U S A 1996, 93(6):2557-2563.

161. Ichiba M, Maeta Y, Mukoyama T, Saeki T, Yasui S, Kanbe T, Okano J, Tanabe Y, Hirooka Y, Yamada S, et al: Expression of 8-hydroxy-2'-deoxyguanosine in chronic liver disease and hepatocellular carcinoma. Liver Int 2003, 23(5):338-345.

162. Schwarz KB, Kew M, Klein A, Abrams RA, Sitzmann J, Jones L, Sharma S, Britton RS, Di Bisceglie AM, Groopman J: Increased hepatic oxidative DNA damage in patients with hepatocellular carcinoma. Dig Dis Sci 2001, 46(10):2173-2178.

163. Feig DI, Reid TM, Loeb LA: Reactive oxygen species in tumorigenesis. Cancer Res 1994, 54(7 Suppl):1890s-1894s.

164. Retter AS, Gulley $J$, Dahut WL: Novel therapeutic strategies in prostate cancer. Cancer Biol Ther 2004, 3(4):371-376.

165. Sikka SC: Role of oxidative stress response elements and antioxidants in prostate cancer pathobiology and chemoprevention-a mechanistic approach. Curr Med Chem 2003, 10(24):2679-2692. 
166. Vincent HK, Innes KE, Vincent KR: Oxidative stress and potential interventions to reduce oxidative stress in overweight and obesity. Diabetes Obes Metab 2007, 9(6):813-839.

167. Mayne ST: Antioxidant nutrients and chronic disease: use of biomarkers of exposure and oxidative stress status in epidemiologic research. $J$ Nutr 2003, 133(Suppl 3):933S-940S.

168. Green J, Kleeman CR: Role of bone in regulation of systemic acid-base balance. Kidney Int 1991, 39(1):9-26.

169. Arnett T: Regulation of bone cell function by acid-base balance. Proc Nutr Soc 2003, 62(2):511-520.

170. Bushinsky DA: Acid-base imbalance and the skeleton. Eur J Nutr 2001, 40(5):238-244

171. Arnett TR: Acidosis, hypoxia and bone. Arch Biochem Biophys 2010, 503(1):103-109.

172. Arnett TR, Dempster DW: Effect of $\mathrm{pH}$ on bone resorption by rat osteoclasts in vitro. Endocrinology 1986, 119(1):119-124.

173. Arnett TR, Spowage M: Modulation of the resorptive activity of rat osteoclasts by small changes in extracellular $\mathrm{pH}$ near the physiological range. Bone 1996, 18(3):277-279.

174. Goldhaber P, Rabadjija L: $\mathrm{H}+$ stimulation of cell-mediated bone resorption in tissue culture. Am J Physiol 1987, 253(1 Pt 1):E90-E98.

175. Kraut JA, Mishler DR, Kurokawa K: Effect of colchicine and calcitonin on calcemic response to metabolic acidosis. Kidney Int 1984, 25(4):608-612.

176. Bushinsky DA, Krieger NS, Geisser DI, Grossman EB, Coe FL: Effects of pH on bone calcium and proton fluxes in vitro. Am J Physiol 1983, 245(2):F204-F209.

177. Bushinsky DA: Net calcium efflux from live bone during chronic metabolic, but not respiratory, acidosis. Am J Physiol 1989, 256(5 Pt 2):F836-F842.

178. Frick KK, Bushinsky DA: Metabolic acidosis stimulates RANKL RNA expression in bone through a cyclo-oxygenase-dependent mechanism. J Bone Miner Res 2003, 18(7):1317-1325.

179. Boyle WJ, Simonet WS, Lacey DL: Osteoclast differentiation and activation. Nature 2003, 423(6937):337-342.

180. Chang L, Karin M: Mammalian MAP kinase signalling cascades. Nature 2001, 410(6824):37-40

181. Nakashima T, Kobayashi Y, Yamasaki S, Kawakami A, Eguchi K, Sasaki H, Sakai H: Protein expression and functional difference of membrane-bound and soluble receptor activator of NF-kappaB ligand: modulation of the expression by osteotropic factors and cytokines. Biochem Biophys Res Commun 2000, 275(3):768-775.

182. Wada T, Penninger JM: Mitogen-activated protein kinases in apoptosis regulation. Oncogene 2004, 23(16):2838-2849.

183. Leibbrandt A, Penninger JM: RANK/RANKL: regulators of immune responses and bone physiology. Ann N Y Acad Sci 2008, 1143:123-150.

184. Gonzalez-Suarez E: RANKL inhibition: a promising novel strategy for breast cancer treatment. Clin Transl Oncol 2011, 13(4):222-228.

185. Ishida N, Hayashi K, Hoshijima M, Ogawa T, Koga S, Miyatake Y, Kumegawa M, Kimura T, Takeya T: Large scale gene expression analysis of osteoclastogenesis in vitro and elucidation of NFAT2 as a key regulator. J Biol Chem 2002, 277(43):41147-41156

186. Takayanagi H, Kim S, Koga T, Nishina H, Isshiki M, Yoshida H, Saiura A, Isobe M, Yokochi T, Inoue J, et al: Induction and activation of the transcription factor NFATc1 (NFAT2) integrate RANKL signaling in terminal differentiation of osteoclasts. Dev Cell 2002, 3(6):889-901.

187. Komarova SV, Pereverzev A, Shum JW, Sims SM, Dixon SJ: Convergent signaling by acidosis and receptor activator of NF-kappaB ligand (RANKL) on the calcium/calcineurin/NFAT pathway in osteoclasts. Proc Natl Acad Sci U S A 2005, 102(7):2643-2648.

188. Mancini M, Toker A: NFAT proteins: emerging roles in cancer progression. Nat Rev Cancer 2009, 9(11):810-820.

189. Buchholz M, Schatz A, Wagner M, Michl P, Linhart T, Adler G, Gress TM, Ellenrieder $V$ : Overexpression of c-myc in pancreatic cancer caused by ectopic activation of NFATc1 and the Ca2+/calcineurin signaling pathway. EMBO J 2006, 25(15):3714-3724.

190. Holzmann K, Kohlhammer H, Schwaenen C, Wessendorf S, Kestler HA Schwoerer A, Rau B, Radlwimmer B, Dohner H, Lichter P, et al: Genomic DNA-chip hybridization reveals a higher incidence of genomic amplifications in pancreatic cancer than conventional comparative genomic hybridization and leads to the identification of novel candidate genes. Cancer Res 2004, 64(13):4428-4433.
191. Koenig A, Linhart T, Schlengemann K, Reutlinger K, Wegele J, Adler G, Singh G, Hofmann L, Kunsch S, Buch T, et al: NFAT-induced histone acetylation relay switch promotes C-Myc-dependent growth in pancreatic cancer cells. Gastroenterology 2010, 138(3):1189-1199 e1181-1182.

192. Masuo T, Okamura S, Zhang Y, Mori M: Cyclosporine A inhibits colorectal cancer proliferation probably by regulating expression levels of c-Myc, p21(WAF1/CIP1) and proliferating cell nuclear antigen. Cancer Lett 2009, 285(1):66-72.

193. Singh G, Singh SK, Konig A, Reutlinger K, Nye MD, Adhikary T, Eilers M, Gress TM, Fernandez-Zapico ME, Ellenrieder V: Sequential activation of NFAT and c-Myc transcription factors mediates the TGF-beta switch from a suppressor to a promoter of cancer cell proliferation. J Bio/ Chem 2010, 285(35):27241-27250.

194. Schwalfenberg GK: The alkaline diet: is there evidence that an alkaline $\mathrm{pH}$ diet benefits health? J Environ Public Health 2012, 2012:727630.

doi:10.1186/1743-7075-9-72

Cite this article as: Robey: Examining the relationship between dietinduced acidosis and cancer. Nutrition \& Metabolism 2012 9:72.

\section{Submit your next manuscript to BioMed Central and take full advantage of:}

- Convenient online submission

- Thorough peer review

- No space constraints or color figure charges

- Immediate publication on acceptance

- Inclusion in PubMed, CAS, Scopus and Google Scholar

- Research which is freely available for redistribution

Submit your manuscript at www.biomedcentral.com/submit
C Biomed Central 